\title{
Influence of Career Development on Performance of Local Non-Governmental Organizations in Kenya
}

\author{
Sebastian Muthama Muema ${ }^{1, *}$, Lawrence Odollo ${ }^{2}$ \\ Department of Commerce, Jomo Kenyatta University of Agriculture and Technology, Nairobi, Kenya \\ Email address: \\ Sebmuema72@gmail.com(S. M. Muema), lodollo70@gmail.com (L. Odollo) \\ ${ }^{*}$ Corresponding author
}

\section{To cite this article:}

Sebastian Muthama Muema, Lawrence Odollo. Influence of Career Development on Performance of Local Non-Governmental Organizations in Kenya. Journal of Business and Economic Development. Vol. 5, No. 4, 2020, pp. 208-213. doi: 10.11648/j.jbed.20200504.12

Received: October 11, 2020; Accepted: October 22, 2020; Published: October 30, 2020

\begin{abstract}
Career development in the recent past has received more attention not only as a concern for the management of human resources, but also as institutional strategic management component for ensuring performance and growth. The purpose of this study therefore was to establish the career development practices on performance of local non-governmental organizations in Kenya. The unit of analysis was the employees working with these local non-governmental organizations. A sample of two hundred and ten employees was drawn from the population. The study used purposive and stratified sampling to sample ten local non-governmental organizations from which simple random sampling was used to get the sample size. The study adopted a cross sectional design. The main instrument for collecting primary data was a questionnaire. Each participating organization filled ten questionnaires. Descriptive and Inferential analysis were used to determine the strength of association between career development and organizational performance. The findings revealed that career development has a significant effects on internal business and significantly contributes to performance of Non-Governmental Organizations. Based on the findings and conclusions, the study recommends that there is need for the NGOs to have well documented human resource plans as well as mechanisms to operationalize them; this should be done with the participation of all the staff and frequent feedback taken for possible modifications. There is need for top management to be sensitized on the potential influence of human resource planning and organizational performance to win their commitment and support.
\end{abstract}

Keywords: Performance, Career Development, NGOs, Stratified Sampling, Strategic Management

\section{Introduction}

In the past, organizations replaced their key staff after they left the organization [1]. One of the common mistakes that the early organizations made was to replace employees rather than to develop them [2]. Other problems that arose from the replacement process, in the early years, included that, in many cases, it was difficult to find the right employee for a new vacancy in a short time period and where the organizations could not find the right person from within, the organizations had to hire from outside, which further increased the replacement costs [3]. Over the years, organizations have realized that they can discover their future key staff from within using career development practices [4].

Kenya is realizing a robust growth in the number of NonGovernmental organizations. The sector has been growing at an average rate of 400 Organizations per year [5]. Many organizations in Kenya today are constantly filling up management and top leadership positions [6]. On the basis of some evidence, several studies (for instance see [8-10]) have reviewed business planning and evidenced concerns related to planning for succession as seen to feature heavily in industries as diverse as those of business and even nonbusiness contexts in other parts of the world with the assertion that a sizeable proportion of businesses lack adequate succession plans. However, the findings of their study only prompt key areas for future research, and key among them is the need to equip existing staff employees to take over top positions when they are left vacant. This prompts the need for career development.

Organization performance measurement is considered a multifaceted concept that occurs at different sectoral levels for industry, corporate and business sectional unit. However, 
there is a necessity to target specific factors which contribute to the performance in a manner that matches context of the organizations with sector factors that can sustain performance over the long term [11].

NGOs which are generally not-for profit, voluntary citizens' groups that are organized on a local, national, or international level to address issues in support of the public good [12].

It is also important to note that NGOs are the recipients of billions of dollars invested in social transformation. This provides a basis for taking into consideration NGOs' performance as a necessary factor to be considered fundamentally to address the question of upwards accountability to the stakeholders such as donors, international aid organisations or foreign governments supporting developing countries, or others with power over them, and downwards accountability to those affected by them that include the stakeholders or direct beneficiaries who are dependent on these organizations [13]. Accountability, transparency, and effectiveness have been crucial for the stakeholders that NGOs serve as direct beneficiaries, donors who fund their programs, and host local governments in the recent past [14]. Organization performance of NGOs is attributed to variety of services and humanitarian assistance functions that are task-oriented targeting people with a common interest [15]. NGOs bring citizens' concerns to governments, monitor policy, program implementation, and encourage participation of civil society organizations at the community level including community based organizations [16].

Though organizations are increasingly acknowledging the critical role of business planning prior to exit of executives, few have plans in place to guide them through the process and as a result decline in organizational performance has often been realized during transition [17-21].

Recent historical events and emerging trends emphasize the need to invest in the active career development of leaders. Despite the fact that executives are increasingly expressing the need to focus on such initiatives, few are actively growing organizational leaders as part of their business strategy [22]. The study identifies that gap that exists when leaders exit organizations leaving organizations with no option but to outsource. As witnessed in the Kenya case, many organizations have experienced turbulent moments in the form of organization wrangles and decreased organizational performance [23].

The purpose of this study therefore was to determine the influence of career development practice on the organizational performance of local non-governmental organizations in Kenya.

\section{Literature Review}

This paper reviewed the Stewardship Theory which is a new perspective to understand the existing relationships between ownership and management of the company [24]. This theory arises as an important counterweight to Agency
Theory.

Stewardship theory has been introduced as a means of defining relationships based upon the premise of human resource capital management [25]. Stewardships theory defines situations in which managers are not motivated by individual goals but rather are stewards whose motives are aligned with the objectives of principals The stewardship theory assumed that board of directors and Chief Executive Officer will act as good stewards of firms' assets and will in fact pursue the interests of the firm, even if the interest of executives differ from family interest. The theory emphasizes that organizations should emphasize on training their employees on career programs that make good stewards of their organizations [26]. Stewardship theory, alternatively argues that the performance of both a manager and the organization for which he or she works is maximized when both the manager (board of directors) and the people who run the firm (the family) create a relationship based on stewardship theory rather than on agency theory [27]. Stewardship theory assumes that individuals are more concerned with their potential to make a contribution to the organizational performance than individualistic desires.

Career development effectiveness is enhanced by the implementation of good succession plans which enable organizations to prepare successors of leadership positions by equipping them with the relevant skills and competencies required [28]. A good succession planning system will look for talent both internally and externally [29]. The taking of talent from outside in extremely advantageous especially if the organization stands to benefit in terms of new ideas or even new technology [30].

\section{Methodology}

This study adopted a cross sectional research design approach that was guided by stratified random sampling with proportional allocation [31]. Stratified random sampling technique was used to select the respondents from each stratum. The sample for each NGO was distributed proportionately based on the number of employees at each stratum. The proportional allocation method is highly recommended when obtaining from different departments [32].

The population was categorized into senior management, junior management, Administrative staff and general staff. The target population of this study was ten NGOs involved in the study. The NGOs formed the unit of analysis. A list of employees was selected by use of stratified sampling. The choice of these staff was based on the fact that they have vast knowledge of the matters relating to business planning in the non-governmental organizations.

A Likert scale was used to measure opinions of the respondents indicating the extent to which they consider items important with regard to career development indicators [33].

Data analysis was performed using SPSS software. The questionnaires collected were numbered to avoid mixing up 
of the questionnaires during data entry into the SPSS. Data cleaning was carried out to ensure that there is no missing information. Cases of missing information was handled by clustering. Both descriptive and inferential statistics were adopted for the study.

\section{Findings}

In total 210 questionnaires were distributed to employees in various departments. A total of 196 questionnaires were reasonably and adequately completed representing 93 percent response rate while 14 questionnaires were not returned. This response rate was deemed satisfactory since 75 percent is the rule of thumb for minimum responses [34]. The high response rate realized in the current study can be attributed to the data collection method that meant involvement of all the levels of employees. Furthermore, the JKUAT introductory letter and NACOSTI research permit were delivered before the actual interviews were conducted which may mean respondents were alerted in advance.

The reponse rate was presented in figure 1 .

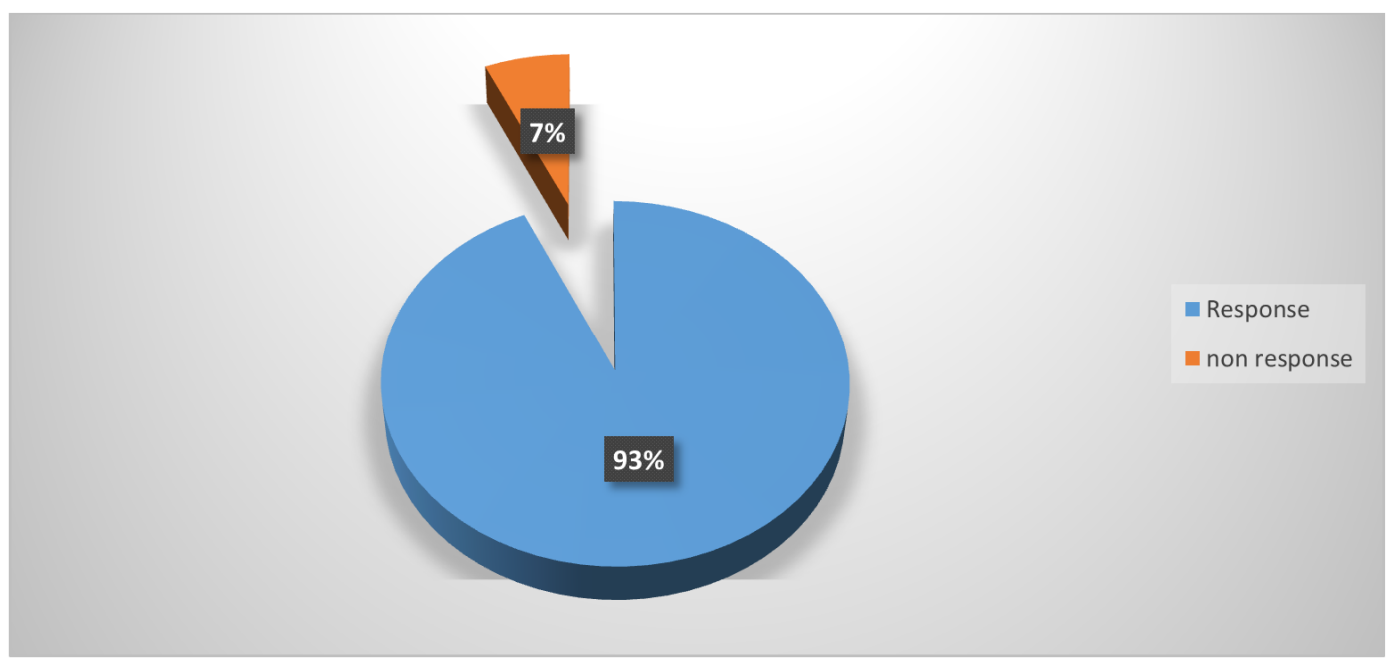

Figure 1. Response Rate.

Table 1. Overall response rate.

\begin{tabular}{lll}
\hline Response & Response Distribution & Percentage \\
\hline Administered Questionnaire & 210 & 100 \\
Returned & 196 & 93 \\
Un-returned & 14 & 7 \\
\hline
\end{tabular}

The results in table 1 show that only fourteen questionnaires were not returned and the return rate was good at 93 percent.

Based on the respondents from the NGOs, $18.4 \%$ of the respondents were from Asante Africa Foundation, 20.4\% of the respondents were from Carolina for Kibera foundation, $16.1 \%$ of the respondents were from FEMNET, 5.1\% of the respondents were from Jamii Bora, $10.2 \%$ of the respondents were from KOMAZA, $10.2 \%$ of the respondents were from Mikindani Center for Hope, $4.6 \%$ of the respondents were from Mando, $4.1 \%$ of the respondents were from Pragya Kenya, 5.1\% of the respondents were from the Youth Café and 5.1\% of the respondents were from Nashulai Maasai Conservancy. This was presented in table 2 .
Table 2. Distribution of respondents based on the Non-Governmental organizations.

\begin{tabular}{lll}
\hline NGO & Response Distribution & Percentage \\
\hline Asante Africa Foundation & 36 & 18.4 \\
Carolina for Kibera & 40 & 20.4 \\
FEMNET & 33 & 16.1 \\
Jamii Bora & 10 & 5.1 \\
KOMAZA & 20 & 10.2 \\
Mikindani Center of HOPE & 20 & 10.2 \\
MANDO & 9 & 4.6 \\
Pragya Kenya & 8 & 4.1 \\
The Youth Cafe & 10 & 5.1 \\
Nashulai Maasai Conservancy & 10 & 5.1 \\
\hline
\end{tabular}

Respondents were asked to state the extent to which they considered strategic career development in the organization important. The 5-scale Likert was used to rate responses as: 1Not at all. 2-To a small extent, 3-To a moderate extent, 4-To a large extent and 5-To a very large extent. The results were presented in table 3.

Table 3. Descriptive statistics for career development

\begin{tabular}{|c|c|c|c|}
\hline Statement & Number & Mean Score & Standard Deviation \\
\hline The organization identifies candidates for promotion based on competences and qualifications. & 196 & 2.68 & 1.371 \\
\hline Decision-makers assess career planning requirements in key positions. & 196 & 3.72 & 1.158 \\
\hline Staff competencies are developed to meet the organization's current and future needs. & 196 & 3.38 & 1.461 \\
\hline The organization uses succession planning needs to train and develop staff appropriately. & 196 & 4.09 & .882 \\
\hline The required skills and knowledge for key positions in the organization are identified. & 196 & 3.14 & 1.413 \\
\hline Average & 196 & 3.27 & 1.059 \\
\hline
\end{tabular}


The results of table 3 indicate that on the statement that the organization identifies candidates for promotion based on competences and qualifications. The mean was 2.68 and the standard deviation was 1.371. On the statement that Decision-makers assess career planning requirements in key positions. The mean was 3.72 and the standard deviation was 1.158. On the statement that Staff competencies are developed to meet the organization's current and future needs. The mean was 3.38 and the standard deviation was 1.461. On the statement that the organization assesses the future needs of human resources periodically. The mean was 3.34 and the standard deviation was 1.407 . On the statement that the organization uses succession planning needs to train and develop staff appropriately. The mean was 4.09 and the standard deviation was 0.882 . On the statement that the required skills and knowledge for key positions in the organization are identified. The mean was 3.14 and the standard deviation was 1.413 . The overall mean was 3.27 and the standard deviation was 1.059 . The results indicate that the mean was above 3 which means most of the organizations somewhat had not embraced career development in their organization. This may be due to inadequate resources. Other studies have also shown that many organizations do not embrace career development as an important component for organizational performance and this leads to poor organizational performance $[6,7,18,21]$.

Inferential analysis was then conducted. The results are presented in table 4.

Table 4. Influence of career development on organizational performance.

\begin{tabular}{lllll}
\hline \multicolumn{2}{l}{ Model Summary } & & \\
\hline Model & R & R Square & Adjusted R Square & Std. Error of the Estimate \\
\hline .504 & .254 & .250 & .47865 \\
\hline
\end{tabular}

\begin{tabular}{cllllll}
\hline ANOVA & & & & & \\
\hline & & Sum of Squares & df & Mean Square & F & Sig. \\
\hline Regression & 15.101 & 1 & 15.101 & .000 \\
\\
Residual & 44.446 & 194 & .229 & \\
Total & 59.547 & 195 & & \\
\hline
\end{tabular}

\begin{tabular}{lllll}
\hline Coefficients & & & \\
\hline & \multicolumn{2}{l}{ Unstandardized Coefficients } & Standardized Coefficients & Sig. \\
\cline { 2 - 4 } & B & Std. Error & Beta & 10.537 \\
(Constant) & 1.996 & .189 & & .000 \\
Career Development & .418 & .051 & .504 & 8.119 \\
\hline
\end{tabular}

Dependent Variable: organization performance.

The results in table 1 indicate that the Pearson correlation coefficient was 0.504 and indicated that career development has a moderate relationship with organizational performance. Career development has a $50.4 \%$ influence on organizational performance. The results indicate that the model fitted on the data was statistically significant. Further, the results imply that the career development is a good predictor of organizational performance of NGOS in Kenya. The Fstatistic was 65.914 on 1 and 194 degrees of freedom with a P-value (0.000) which indicates that career development was significant.

The regression analysis was performed to discover the amount of contribution of career development on organization performance. The results showed that an increase in career development by 0.418 would lead to an increase in performance by 1 unit $(\beta=0.418, t=$ $8.119, P=0.000<0.05)$.

\section{Conclusions}

Career development practices were found to have significant effects on stakeholder's outcomes that is a component of organization performance. Keeping up-to-date with advances about what works (does not work) to improve performance, employees have high level of understanding of organizations strategic orientation, stakeholders consider organizations work relevant, communities taking ownership of the projects and programs implemented and financial and narrative reports clearly indicate activity outcome, are all important aspects of organization performance that can be promoted with career development.

Institutional growth is a key component of organization performance. It is the case in this study that, indeed career development contributes positively to organizational performance based on teamwork where work teams frequently review and evaluate processes, incidents, decisions and innovations to derive as much learning as they can from both success and failure through performance appraisal and promoting commitment to the organization for growth and development as well as career development within the organization.

\section{Recommendations}

There is need for the NGOs to have well documented human resource plans as well as mechanisms to operationalize them; this should be done with the participation of all the staff and frequent feedback taken for possible modifications. There is need for top management to be sensitized on the potential influence of career 
development and organizational performance to win their commitment and support. There is need for the NGOs to develop career development guidelines and have each and every employee develop meaningful individual accountability plans clearly outlining their objectives and their career aspirations in line with the guidelines.

\section{References}

[1] Bernthal, P., \& Wellins, R. (2006). Trends in leader development and succession. People and Strategy.

[2] Cheng, J. (2016). Preparing for Top Management Changes: The Relationship between Succession Planning Processes and Succession Outcomes. Strategic Management Society Annual Conference, Harvard Business School.

[3] Drotter, S. J., \& Charan, R. (2011). Building leaders at every level: A leadership pipeline. Ivey Business Journal, 65 (5), 2135 .

[4] Groves, K. S. (2013). Integrating leadership development and succession planning best practices. Journal of Management Development, 26 (3), 239-253.

[5] Byham, W. C. (2002). A new look at succession management. Ivey Business Journal, 66 (5), 10-12.

[6] Odhiambo, J., Njanja L., \& Zakayo, C. (2014). Effects of Succession Planning Practices on Organizational Performance among the Non-governmental Organizations in Kenya. European Journal of Business Management, 2 (1), 141-154.

[7] Ngandu, P. (2017). The Succession Planning Concept and how the church leadership of the Adventist Educational Institution in Africa Perceive the Succession Plans. Dissertation Abstracts, 2 (9), 5. (UMI No. 322056814).

[8] Cingoranellí, D. (2009). A 2009 tune-up for your firm's succession planning. Journal of Accountancy, 207 (3), 42-46.

[9] Leibman, M., Bruer, R. A., \& Maki, B. R. (1996). Succession management: The next generation of succession planning. Human Resource Planning, 19 (3), 16-29.

[10] Kunreuther, F. (2005). Up next: Generation Change and the Leadership of Nonprofit Organizations. Annie E. Casey Executive Transitions Monograph Series, 4, 1-21.

[11] McGahan, A. M. (2004). How Industries Evolve: Principles for Achieving and Sustaining Superior Performance. Boston: Harvard Business School Press.

[12] Benton, A. \& Austin, M. J. (in press). Managing Nonprofit Mergers: The Challenges Facing Human Service Organizations. Administration in Social Work.

[13] Bendell, J. (2006). Debating NGO accountability. Geneva, Switzerland: United Nations Press. Retrieved July 2, 2012 from http://www.un.org/liasion/services/dossier.

[14] Collins, S. K. \& Collins, K. S. (2007). Changing workforce demographics necessitates succession planning in health care. The Health Care Manager, 26 (4), 318-325.

[15] Lauder, H. (2015). Human capital theory, the power of transnational companies and a political response in relation to education and economic development. Compare: A Journal of
Comparative and International Education, 45 (3), 490-493.

[16] DeMars, W. E. (2005). NGOs and Transnational Networks: Wild Cards in World Politics. London: Pluto Press.

[17] Austin, M. J., \& Salkowtiz, T. (2009). Executive development \& succession planning: A growing challenge for the American Jewish community. New York, NY: Jewish Funders Network.

[18] Bell, J., Moyers, R., \& Wolfred, T. (2006). Daring to lead: A national study of nonprofit executive leadership. Washington, D. C: Meyer Foundation/CompassPoint Nonprofit Services.

[19] Garman, A. N., \& Glawe, J. (2004). Succession planning. Consulting Psychology Journal: Practice and Research, 56 (2), 119-128.

[20] Santora, J. C., Caro, M. E., \& Sarros, J. C. (2007). Succession in nonprofit organizations: An insider/outsider perspective. Sam Advanced Management Journal, 72 (4), 26-31.

[21] Okwakpam, J. A. (2019). EFFECTIVE SUCCESSION PLANNING: A ROADMAP TO EMPLOYEE RETENTION. Kuwait Chapter of the Arabian Journal of Business and Management Review, 8 (2), 1-10.

[22] Les kiw, L. \& ing h, P. 2007. Leadership development: Learning from best practices. Leadership \& Organizational Development Journal, 28 (5), 444-4 64.

[23] NGOs Co-Ordination Board. (2013). Retrieved 29 October 2015, from http://www.ngobureau.or.ke.

[24] Davis, J. H., Schoorman, D. L., \& Donaldson, L. (1997). Towards a stewardship theory of management. Academy of Management Review, 22 (1), 20-47.

[25] Davis, H., Schoorman, D., \& Donaldson, L. (1997). Toward a stewardship theory of management. Academy of Management Review, 22 (1), 20-47.

[26] Adebola, S. (2019). Why do organisations run talent programmes? Insights from UK organisations. In Managing Talent (pp. 187-213). Palgrave Macmillan, Cham. https://doi.org/10.1007/978-3-319-95201-7_9.

[27] Davis, P., \& Stern, D. (1988). Adaptation, survival, and growth in the family business: An integrated systems perspective. Family Business Review, 1 (1), 69-84.

[28] Lamoureux, K., Campbell, M., \& Smith, R. (2009). Highimpact succession management. Executive summary. Retrieved from North Carolin.

[29] Marrelli, A. (2010). Call to Action: Improving First-Level Supervision of Federal Employees. New York. Diane Publishing.

[30] Roddy, N. (2004). Leadership Capacity Building Model: Developing Tomorrow's Leadership in Science and Technology. Public Personnel International Journal of Scientific and Research Publications, Volume 6, Issue 4, April 2016601 ISSN 2250-3153 www.ijsrp.orgManagement, 33 (4), 503-512. http://dx.doi.org/10.1177/009102600403300410.

[31] Sekaran, U, \& Bougie R., (2016). Research methods for business: A skill building approach, $7^{\text {th }}$ ed. Wiley ISBN 978-1119-16555-2.

[32] Saunders, M. N. K., Lewis, P., \& Thornhill, A. (2009). Research Methods for Business Students (5th ed.). Harlow, United Kingdom: FT Prentice Hall. 
[33] Likert, R. (1932). A technique for the measurement of attitudes. Archives of Psychology, 22 140, 55.
[34] Kothari, (2006). Research Methodology: Methods and Techniques. Mumbai: New Age International (P) Ltd. 